\title{
Density of Ternary Blends with Biodiesel, Diesel Fuel and Isopropanol at Different Temperatures
}

\begin{abstract}
IRINA NITA ${ }^{1}$, SIBEL OSMAN ${ }^{1 *}$, OLGA IULIAN², RALUCA GEORGIANA SANDU²
${ }^{1}$ University Ovidius of Constanta, Faculty of Applied Sciences and Engineering, 124 Mamaia, 900521, Constanta, Romania

2 University Poltehnica of Bucharest, Faculty of Applied Chemistry and Materials Science, 132 Calea Grivitei, 010737, Bucharest, Romania

The growth in environment pollution as a result of fossil fuels increased consumption has led scientists to focus on biofuels such as biodiesel and bioalcohols. The ternary blends of bioalcohols with fossil fuels and biodiesel show better properties as fuels for diesel engine, than binary blends of biodiesel with diesel fuel. The purpose of this work is to report experimental density data for biodiesel+diesel fuel+isopropanol pseudo-ternary system at atmospheric pressure, covering the whole composition range and for temperature ranging from 293.15 to $323.15 \mathrm{~K}$. Based on experimental data, the accuracy of different mixing rules and empirical equations used to calculate the density of the pseudo-ternary system has been evaluated.
\end{abstract}

Keywords: biodiesel, diesel fuel, isopropanol, density, ternarymixture.

As a result of the increasingly pollution of the environment recorded in recent years, especially due to the transport sector, efforts are being made aimed at reducing harmful

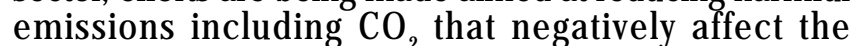
environment. One of the solutions would be finding some alternatives sources of energy such as renewable fuels.

Proven to be environmentally friendly, biodiesel and bioalcohols are part of the renewable fuels category providing a cleaner environment [1-6]. Bioalcohols are an alternative to petroleum-based fuels, the most studied alcohol being ethanol due to its profitability. But, when ethanol is mixed with diesel fuel, a phase separation may occur in the blend. In order to solve such problems, the use of alcohols with higher carbon chain, which have better fuel properties such as higher cetane number, higher calorific value and lower latent heat of evaporation has been proposed [ 7,8$]$. Such alcohols can be easily blended with both diesel fuel and biodiesel at any ratios with no phase separation [8-10]. Moreover, bioalcohols have recently become competitive due to some improved methods of production [11-14].

Most studies on fossil fuel blends with isopropanol refer to engine performance [15-17]. Liu et al. [16] and Hazar and Uyar [17] have investigated mixtures of diesel fuel with isopropanol as additive and have analyzed the behavior and emissions of a diesel engine. They found that isopropanol presence in the blends caused smoke emissions decrease and $\mathrm{NO}$ increase.

There are only few studies on blends with isopropanol regarding properties like density and viscosity, the most relevant physicochemical properties in the combustion process taking place in diesel engine. Gülüm and Bilgin [18] have reported densities at $15^{\circ} \mathrm{C}$ and kinematic viscosities at $40^{\circ} \mathrm{C}$ for canola oil biodiesel+diesel fuel+isopropanol ternary blend with reduced content of alcohol.

More investigations on the physicochemical properties of the biodiesel+diesel fuel+isopropanol ternary system are needed as a result of the lack of data in literature.

The study of the physicochemical properties of binary and ternary fuel mixtures is in our attention [19-22]. The aim of this paper is the study of the diesel fuel system with two biofuels, biodiesel and isopropanol, considering that the addition of isopropanol to the biodiesel blend with diesel fuel allows the addition of higher amounts of biodiesel, while fulfilling the quality standards requirements. Therefore, ternary mixtures of biodiesel+diesel fuel+isopropanol have been prepared to cover the whole composition range and their densities have been determined for temperature between $293.15 \mathrm{~K}$ and 323.15 $\mathrm{K}$. The accuracy of several predictive and correlative equations used to calculate the density of fuels blends has been evaluated.

\section{Experimental part}

Diesel fuel was purchased from a local company and biodiesel from SGS Bulgaria Ltd. The two fuels properties are in accordance with quality standard requirements: EN 590 for diesel fuel and EN14214 for biodiesel. Isopropanol was purchased from Merck Company ( $99.7 \%$ v/v purity). Table 1 lists some important properties of biodiesel, diesel fuel and isopropanol, and their molar masses. The biodiesel

Table 1

PROPERTIES OF DIESEL FUEL, BIODIESEL AND ISOPROPANOL

\begin{tabular}{|c|c|c|c|c|c|c|c|c|}
\hline \multirow[t]{2}{*}{ Property } & \multirow[t]{2}{*}{ Unit } & \multirow{2}{*}{$\begin{array}{c}\text { Test } \\
\text { method }\end{array}$} & \multicolumn{2}{|c|}{ Diesel fuel } & \multicolumn{2}{|c|}{ Biodiesel } & \multicolumn{2}{|c|}{ Isopropanol } \\
\hline & & & EN590 & exp. & EN 14214 & exp. & $\begin{array}{c}\text { lit. } \\
\left(25^{\circ} \mathrm{C}\right)\end{array}$ & $\begin{array}{c}\text { exp. } \\
\left(25^{\circ} \mathrm{C}\right)\end{array}$ \\
\hline $\begin{array}{l}\text { Density at } \\
15^{\circ} \mathrm{C}\end{array}$ & $\mathrm{g} / \mathrm{cm}^{3}$ & $\begin{array}{l}\text { ENISO } \\
12185\end{array}$ & $0.820-0.845$ & 0.8405 & $0.860-0.900$ & 0.8838 & $\begin{array}{l}0.7812^{*}[23] \\
0.7810^{*}[24]\end{array}$ & $0.7909^{8}$ \\
\hline $\begin{array}{l}\text { Viscosity at } \\
40^{\circ} \mathrm{C}\end{array}$ & $\mathrm{mm}^{2} / \mathrm{s}$ & $\begin{array}{c}\text { ENISO } \\
3104\end{array}$ & $2.0-4.5$ & 2.6791 & $3.50-5.00$ & 4.4189 & $\begin{array}{l}2.6158 *[25] \\
2.6384^{*}[26]\end{array}$ & 2.6081 \\
\hline Flash point & ${ }^{\circ} \mathrm{C}$ & $\begin{array}{c}\text { ENISO } \\
2719\end{array}$ & $>55$ & 64 & $>101$ & 175 & - & - \\
\hline $\begin{array}{l}\text { Mean molar } \\
\text { mass }\end{array}$ & $\mathrm{g} / \mathrm{mol}$ & & - & 210.01 & - & 295.18 & 60.1 & - \\
\hline
\end{tabular}

${ }^{\circ}$ calculated from dynamic viscosity and density at $25^{\circ} \mathrm{C}$ 


\begin{tabular}{|l|c|c|c|}
\hline \multicolumn{1}{|c|}{ Name of Fatty acid* } & $\begin{array}{c}\text { Molecular } \\
\text { formula }\end{array}$ & $\begin{array}{c}\text { Molar } \\
\text { mass } \\
(\mathrm{g} / \mathbf{m o l})\end{array}$ & $\begin{array}{c}\text { Fatty acid methyl ester } \\
\text { composition (\% w/w) }\end{array}$ \\
\hline Lauric (C12:0) & $\mathrm{C}_{13} \mathrm{H}_{26} \mathrm{O}_{2}$ & 214.344 & - \\
\hline Miristic (C14:0) & $\mathrm{C}_{15} \mathrm{H}_{30} \mathrm{O}_{2}$ & 242.398 & - \\
\hline Palmitic (C16:0) & $\mathrm{C}_{16} \mathrm{H}_{32} \mathrm{O}_{2}$ & 270.456 & 3.47 \\
\hline Stearic (C18:0) & $\mathrm{C}_{18} \mathrm{H}_{36} \mathrm{O}_{2}$ & 298.510 & 1.32 \\
\hline Arachidic (eicosenoic) (C20:0) & $\mathrm{C}_{20} \mathrm{H}_{40} \mathrm{O}_{2}$ & 326.563 & 0.38 \\
\hline Palmitoleic (C16:1) & $\mathrm{C}_{16} \mathrm{H}_{30} \mathrm{O}_{2}$ & 268.440 & - \\
\hline Oleic (C18:1) & $\mathrm{C}_{18} \mathrm{H}_{34} \mathrm{O}_{2}$ & 296.494 & 39.22 \\
\hline Linoleic (C18:2) & $\mathrm{C}_{18} \mathrm{H}_{32} \mathrm{O}_{2}$ & 294.478 & 39.52 \\
\hline Linolenic (C18:3) & $\mathrm{C}_{18} \mathrm{H}_{30} \mathrm{O}_{2}$ & 292.462 & - \\
\hline 11-Octadecenoic (11-vacenic) (C19:2) & $\mathrm{C}_{19} \mathrm{H}_{34} \mathrm{O}_{2}$ & 282.461 & 15.09 \\
\hline Gadoleic (11-eicosenoic) (C20:1) & $\mathrm{C}_{21} \mathrm{H}_{40} \mathrm{O}_{2}$ & 324.541 & 0.75 \\
\hline
\end{tabular}

*The first digit indicates the number of carbon atoms in the acid chain of the methyl ester

and the second digit indicates the number of double bonds of carbon atoms in the acid chain of the methyl ester.

mean molar mass was determined by cryometric method and based on chemical composition presented in Table 2. The mean molar mass of diesel fuel was determined by cryometric method. The monoalkyl esters composition of biodiesel was determined by gas chromatography using a Clarus 500 GC chromatograph equipped with a FID detector and capillary column SGE BPX70 of high polarity, with polysiloxane as stationary phase and hydrogen carrying gas at a flow rate of $20 \mathrm{~mL} / \mathrm{min}$.

Ternary biodiesel+diesel fuel+ isopropanol blends were prepared at room temperature by w eighting; the analytical balance has $\pm 0.0001 \mathrm{~g}$ accuracy. Twenty two mixtures were prepared to cover the entire compositions range of the ternary system. All mixtures were completely miscible. The biodiesel+diesel fuel+ isopropanol system is a pseudoternary system due to the fact the diesel fuel and biodiesel are complex mixtures; diesel fuel is a blend of hydrocarbons, and biodiesel is a blend of mono alkyl esters of fatty acids.

An Anton Paar SVM 3000 equipment provided with a Ushaped vibrating tube as cell for density measurement was used for density measurement. The device is equipped with a Peltier integrated thermostat, the accuracy of which is \pm $0.02{ }^{\circ} \mathrm{C}$ and the uncertainty for density measurement is \pm $0.0005 \mathrm{~g} / \mathrm{cm}^{3}$. To achieve the experimental determinations, $5 \mathrm{ml}$ of sample are required. The density data is provided at a specified temperature. Density was measured at 293.15 $\mathrm{K}, 298.15 \mathrm{~K}, 303.15 \mathrm{~K}, 308.15 \mathrm{~K}, 313.15 \mathrm{~K}$ and 323.15K.

\section{Equations}

Experimental data has been used to test some equations for correlation and prediction of ternary system density. The correlative equations are density-composition (or temperature) equations containing one or more correlation parameters obtained by regression of experimental data. Predictive equations allow the property to be estimated based on the properties of the pure components without the use of blend experimental data. Equations for density calculation of the ternary system were obtained by expanding those for the binary systems. Although in practice many equations use volume fractions, for the accuracy of the calculations in this work mass fractions or molar fractions were employed to express the composition of the ternary sytem. A new equation with six parameters was tested for density calculation of the studied system.

For the dependence density-composition, equations used for density prediction are eq.(1) and eq.(2), and for correlation, eq. (3). The correlation with temperature was realised with eq.(4).
Eq.(1) is the mixing rule of Kay, one of the most widely used method for the prediction of the density of petroleum products and of fossil fuels + biofuels blends [27-30]:

$$
\rho=w_{1} \rho_{1}+w_{2} \rho_{2}+w_{3} \rho_{3}
$$

where $\rho$ is the density of the blend, $\rho_{i}$ and $w_{i}$ are the densities and the mass fraction of the blend components, respectively.

Eq.(2) taken from the field of petroleum products calculates the density of the ternary system:

$$
\rho=\frac{x_{1} M_{1}+x_{2} M_{2}+x_{3} M_{3}}{\frac{x_{1} M_{1}}{\rho_{1}}+\frac{x_{2} M_{2}}{\rho_{2}}+\frac{x_{3} M_{3}}{\rho_{3}}}
$$

where $M_{i}$ is the molar mass of component $i$, and $x_{i}$ is the molar fractions of the three components of the blend.

Eq.(3) is an empirical polynomial equation obtained with Statistical V10 program, including six adjustable parameters, $a, b, c, d$, e and $f$.

$$
\rho=a w_{1}+b w_{2}+c w_{3}+d w_{1} w_{2}+e w_{1} w_{3}+f w_{2} w_{3}
$$

For density-temperature correlation, an empirical equation proposed by Yuan [31] and applied by Tesfa [32] for binary sistems was used for the ternary system:

$$
\rho=a T+b
$$

where $T$ is the temperature $(K), a, b$ are the fitting parameters.

Each equation (eqs. (1)-(4)) calculating the density of ternary system was tested for every sample, and the results were compared with the experimental values.

The accuracy of the equations was evaluated by the means of the average absolute percentage deviation ( $A A D$ $\%)$ and relative percent deviation (RPD\%):

$$
\begin{aligned}
& A A D=\frac{100}{N} \sum_{i}^{n} \frac{\left|\rho_{\text {exp }, i}-\rho_{\text {cali, } i}\right|}{\rho_{\text {exp }, i}} \\
& R P D=\frac{\rho_{\text {exp }, i}-\rho_{\text {cal }, i}}{\rho_{\text {exp }, i}} \cdot 100
\end{aligned}
$$

where $\rho_{\text {expo,i }}$ and $\rho_{\text {calli, }}$ are the experimental and the calculated value of the ensity, respectively; $N$ represents the number of experimental points. 


\section{Results and discussions}

Experimental data

Experimental data of density of biodiesel+diesel fuel+isopropanol pseudo-ternary system are shown in table 3 at temperatures between 293.15 and $323.15 \mathrm{~K}$. Figure 1 shows density variation with composition at 298.15 $\mathrm{K}$, and figure 2 presents density variation with temperature. The graphical representation at 298.15K was made to better illustrate the density dependence on composition for the studied ternary system. Similar shapes of the curves were obtained for the other investigated temperatures.

From figure 1 itcan be observed that the smallest density correspond to ternary blends with the greatest alcohol content, while the greater density correspond to ternary blends with the greater biodiesel content. As shown in figure 2, densities of all samples decrease with the increase of the temperature, as expected.
Density calculation

The density of ternary blends was correlated with composition (eqs.(1-3)), and temperature (eq. (4)). Tables 4 and 5 present the values obtained for the percentage relative deviation (RPD) using eq.(1) and eq.(2) for the predictive calculation of the density of the biodiesel + diesel fuel + isopropanol ternary system from the densities and the molar masses of the pure components at the studied temperatures. For the evaluation and validation of these equations, the average percentage deviation $(A A D)$ was also calculated. According to the data presented in tables 4 and 5, it can be seen that eq.(1) and eq.(2) allow a prediction of the ternary system density with low errors of $0.60-0.70 \%$ and $0.48-0.56 \% A A D$ respectively.

Table 6 presents the results of the density calculation with eq. (3): equation parameter values and average absolute percentage deviation values $(A A D, \%)$. Eq.(3)

Table 3

EXPERIMENTAL DENSITY VALUES ( $\mathrm{g} / \mathrm{cm}^{3}$ ) OF BIODIESEL (1) + DIESEL FUEL (2) + ISOPROPANOL (3) TERNARY SYSTEM AT DIFFERENT TEMPERATURES

\begin{tabular}{|c|c|c|c|c|c|c|c|c|}
\hline \multicolumn{2}{|c|}{ Composition } & \multicolumn{9}{c|}{ Temperature (K) } \\
\hline w1 & w2 & $\mathbf{2 9 3 . 1 5}$ & $\mathbf{2 9 8 . 1 5}$ & $\mathbf{3 0 3 . 1 5}$ & $\mathbf{3 0 8 . 1 5}$ & $\mathbf{3 1 3 . 1 5}$ & $\mathbf{3 1 8 . 1 5}$ & $\mathbf{3 2 3 . 1 5}$ \\
\hline 0.8116 & 0.0966 & 0.8636 & 0.8598 & 0.8560 & 0.8527 & 0.8489 & 0.8451 & 0.8413 \\
\hline 0.6928 & 0.2082 & 0.8593 & 0.8555 & 0.8518 & 0.8480 & 0.8442 & 0.8406 & 0.8367 \\
\hline 0.6176 & 0.1960 & 0.8499 & 0.8460 & 0.8421 & 0.8382 & 0.8343 & 0.8304 & 0.8264 \\
\hline 0.6206 & 0.0985 & 0.8442 & 0.8402 & 0.8362 & 0.8322 & 0.8281 & 0.8241 & 0.8201 \\
\hline 0.5147 & 0.3921 & 0.8501 & 0.8463 & 0.8426 & 0.8388 & 0.8350 & 0.8313 & 0.8274 \\
\hline 0.4158 & 0.3959 & 0.8411 & 0.8372 & 0.8333 & 0.8294 & 0.8256 & 0.8216 & 0.8176 \\
\hline 0.4179 & 0.2984 & 0.8362 & 0.8322 & 0.8282 & 0.8247 & 0.8206 & 0.8166 & 0.8125 \\
\hline 0.4199 & 0.1999 & 0.8310 & 0.8270 & 0.8229 & 0.8188 & 0.8147 & 0.8105 & 0.8063 \\
\hline 0.4220 & 0.1005 & 0.8266 & 0.8225 & 0.8183 & 0.8141 & 0.8099 & 0.8057 & 0.8022 \\
\hline 0.2153 & 0.1025 & 0.8092 & 0.8050 & 0.8008 & 0.7965 & 0.7922 & 0.7878 & 0.7833 \\
\hline 0.2142 & 0.2040 & 0.8135 & 0.8093 & 0.8052 & 0.8009 & 0.7967 & 0.7924 & 0.7880 \\
\hline 0.2121 & 0.4039 & 0.8223 & 0.8183 & 0.8143 & 0.8102 & 0.8060 & 0.8018 & 0.7975 \\
\hline 0.2100 & 0.5999 & 0.8324 & 0.8285 & 0.8246 & 0.8207 & 0.8167 & 0.8128 & 0.8088 \\
\hline 0.3119 & 0.5940 & 0.8430 & 0.8393 & 0.8355 & 0.8317 & 0.8279 & 0.8241 & 0.8203 \\
\hline 0.1050 & 0.7999 & 0.8335 & 0.8297 & 0.8260 & 0.8223 & 0.8185 & 0.8147 & 0.8109 \\
\hline 0.1061 & 0.6059 & 0.8232 & 0.8193 & 0.8153 & 0.8112 & 0.8072 & 0.8031 & 0.7989 \\
\hline 0.1071 & 0.4080 & 0.8143 & 0.8102 & 0.8061 & 0.8019 & 0.7977 & 0.7934 & 0.7891 \\
\hline 0.1077 & 0.3075 & 0.8093 & 0.8052 & 0.8010 & 0.7963 & 0.7925 & 0.7882 & 0.7839 \\
\hline 0.1088 & 0.1036 & 0.8007 & 0.7965 & 0.7921 & 0.7878 & 0.7835 & 0.7790 & 0.7745 \\
\hline 1 & 0 & 0.8785 & 0.8749 & 0.8712 & 0.8676 & 0.8639 & 0.8603 & 0.8567 \\
\hline 0 & 1 & 0.8365 & 0.8329 & 0.8294 & 0.8258 & 0.8224 & 0.8187 & 0.8152 \\
\hline 0 & 0 & 0.7953 & 0.7909 & 0.7865 & 0.7820 & 0.7775 & 0.7728 & 0.7681 \\
\hline
\end{tabular}

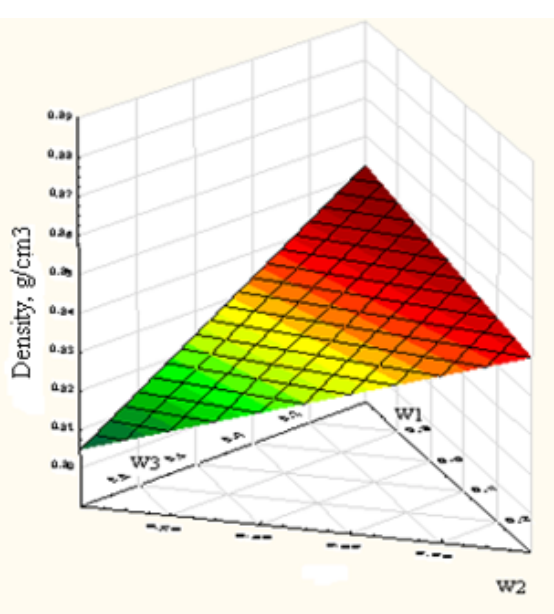

Fig.1. Density variation with composition at $298.15 \mathrm{~K}$ for biodiesel(1) + diesel fuel(2) + isopropanol(3) ternary system

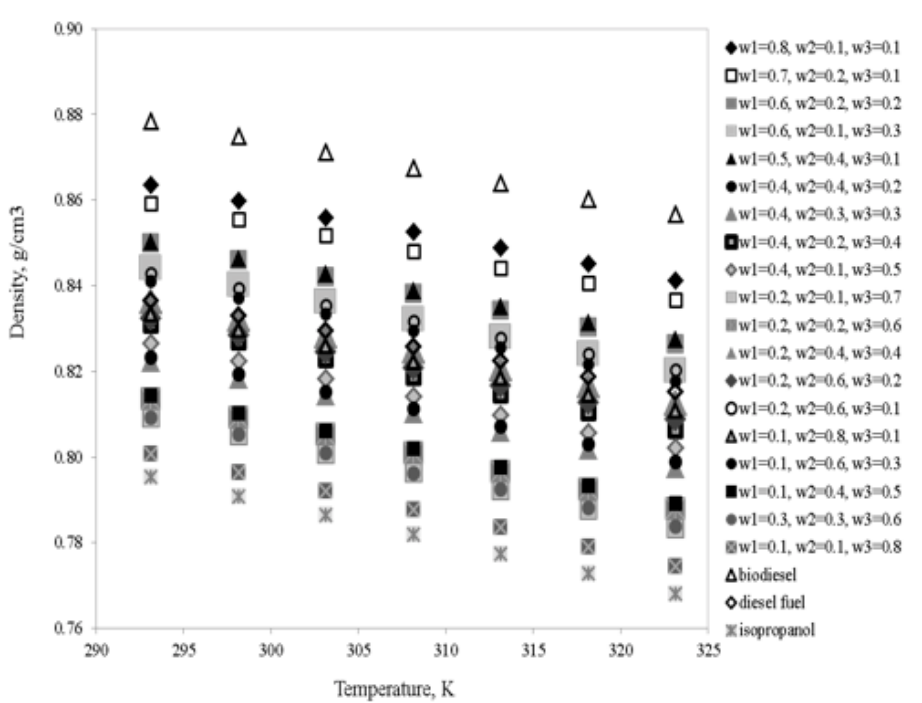

Fig. 2. Density variation with temperature for biodiesel(1)+diesel fuel(2)+isopropanol(3) ternary system at different compositions 
Table 4

RELATIVE PERCENTAGE DEVIATION ( $R P D, \%)$ AND AVERAGE ABSOLUTE PERCENTAGE DEVIATION (AAD, \%) VALUES FOR DENSITY ESTIMATION WITH EQ.(1)

\begin{tabular}{|c|c|c|c|c|c|c|c|c|}
\hline \multicolumn{2}{|c|}{ Composition } & \multicolumn{7}{|c|}{ Temperature (K) } \\
\hline \multirow{2}{*}{$\mathbf{w}_{1}$} & \multirow{2}{*}{$w_{2}$} & 293.15 & 298.15 & 303.15 & 308.15 & 313.15 & 318.15 & 323.15 \\
\hline & & \multicolumn{7}{|c|}{ RPD(\%) } \\
\hline 0.8116 & 0.0966 & -0.3708 & -0.3871 & -0.3953 & -0.3519 & -0.3600 & -0.3722 & -0.3868 \\
\hline 0.6928 & 0.2082 & -0.2584 & -0.2737 & -0.2717 & -0.2860 & -0.2971 & -0.2829 & -0.3096 \\
\hline 0.6176 & 0.1960 & 0.5719 & 0.5924 & 0.6081 & 0.6267 & 0.6428 & 0.6549 & 0.6840 \\
\hline 0.6206 & 0.0985 & 0.8045 & 0.8292 & 0.8479 & 0.8696 & 0.8987 & 0.9129 & 0.9296 \\
\hline 0.5147 & 0.3921 & -0.4915 & -0.5086 & -0.5124 & -0.5285 & -0.5481 & -0.5455 & -0.5767 \\
\hline 0.4158 & 0.3959 & 0.6075 & 0.6282 & 0.6488 & 0.6676 & 0.6790 & 0.7010 & 0.7328 \\
\hline 0.4179 & 0.2984 & 0.7368 & 0.7611 & 0.7843 & 0.7445 & -0.7802 & 0.7912 & 0.8219 \\
\hline 0.4199 & 0.1999 & -0.8995 & -0.9154 & -0.9411 & -0.9651 & -0.9891 & -1.0142 & -1.0445 \\
\hline 0.4220 & 0.1005 & -0.9617 & -0.9808 & -1.0086 & -1.0347 & -1.0583 & -1.0719 & -0.9998 \\
\hline 0.2153 & 0.1025 & -1.0178 & -1.0299 & -1.0407 & -1.0571 & -1.0735 & -1.0845 & -1.1112 \\
\hline 0.2142 & 0.2040 & 0.9867 & 1.0085 & 1.0178 & 1.0453 & 1.0628 & 1.0736 & 1.1025 \\
\hline 0.2121 & 0.4039 & -0.8861 & -0.9018 & -0.9200 & -0.9437 & -0.9876 & -1.0099 & -1.0552 \\
\hline 0.2100 & 0.5999 & -0.6112 & -0.6319 & -0.6576 & -0.6764 & -0.7198 & -0.7271 & -0.7617 \\
\hline 0.3119 & 0.5940 & 0.3229 & 0.3273 & 0.3471 & 0.3625 & 0.3887 & 0.3950 & 0.4158 \\
\hline 0.1050 & 0.7999 & -0.4192 & -0.4360 & -0.4493 & -0.4531 & -0.4874 & -0.4916 & -0.5155 \\
\hline 0.1061 & 0.6059 & 0.7152 & 0.7271 & 0.7576 & 0.7911 & 0.8261 & 0.8456 & 0.8931 \\
\hline 0.1071 & 0.4080 & 0.8255 & 0.8435 & 0.8654 & 0.8904 & 0.9245 & 0.9453 & 0.9768 \\
\hline 0.1077 & 0.3075 & -0.9426 & -0.9514 & -0.9754 & -1.0532 & -1.0234 & -1.0323 & -1.0491 \\
\hline \multirow[t]{3}{*}{0.1088} & 0.1036 & 0.9886 & 0.9900 & 1.0169 & 1.0213 & 1.0270 & 1.0359 & 1.0476 \\
\hline & & \multicolumn{7}{|c|}{$\mathrm{AAD}(\%)$} \\
\hline & & 0.6099 & 0.6238 & 0.6393 & 0.6531 & 0.6716 & 0.6812 & 0.7006 \\
\hline
\end{tabular}

RELATIVE PERCENTAGE DEVIATION (RPD, \%) AND AVERAGE ABSOLUTE PERCENTAGE DEVIATION (AAD, \%) VALUES FOR DENSITY ESTIMATION WITH EQ.(2)

\begin{tabular}{|c|c|c|c|c|c|c|c|c|}
\hline \multicolumn{2}{|c|}{ Composition } & \multicolumn{7}{|c|}{ Temperature (K) } \\
\hline \multirow[b]{2}{*}{$x_{1}$} & \multirow[b]{2}{*}{$\mathbf{x}_{2}$} & 293.15 & 298.15 & 303.15 & 308.15 & 313.15 & 318.15 & 323.15 \\
\hline & & \multicolumn{7}{|c|}{ RPD (\%) } \\
\hline 0.5804 & 0.0971 & -0.1156 & -0.1290 & -0.1354 & -0.0890 & -0.0956 & -0.1035 & -0.1148 \\
\hline 0.4708 & 0.1989 & 0.1052 & 0.0929 & 0.0959 & 0.0848 & 0.0739 & 0.0925 & 0.0685 \\
\hline 0.3415 & 0.1524 & -0.2311 & -0.2480 & -0.2618 & -0.2765 & -0.2912 & -0.2979 & -0.3231 \\
\hline 0.2902 & 0.0647 & -0.5042 & -0.5237 & -0.5383 & -0.5542 & -0.5790 & -0.5857 & -0.5957 \\
\hline 0.3378 & 0.3617 & 0.0785 & 0.0933 & 0.0973 & 0.1111 & 0.1320 & 0.1257 & 0.1555 \\
\hline 0.2192 & 0.2934 & -0.2976 & -0.3166 & -0.3378 & -0.3550 & -0.3680 & -0.3870 & -0.4181 \\
\hline 0.1873 & 0.1880 & 0.4731 & 0.4954 & 0.5183 & 0.4764 & 0.5127 & 0.5200 & 0.5490 \\
\hline 0.1635 & 0.1094 & -0.6559 & -0.6686 & -0.6926 & -0.7129 & -0.7355 & -0.7555 & -0.7820 \\
\hline 0.1451 & 0.0485 & -0.7082 & -0.7222 & -0.7458 & -0.7661 & -0.7853 & -0.7914 & -0.7127 \\
\hline 0.0580 & 0.0388 & -0.9131 & -0.9227 & -0.9318 & -0.9454 & -0.9601 & -0.9672 & -0.9906 \\
\hline 0.0638 & 0.0854 & 0.9420 & 0.9635 & 0.9736 & 1.0006 & 1.0194 & 1.0289 & 1.0576 \\
\hline 0.0796 & 0.2130 & -0.8580 & -0.8753 & -0.8966 & -0.9220 & -0.9701 & -0.9935 & -1.0417 \\
\hline 0.1057 & 0.4244 & 0.4900 & 0.5117 & 0.5400 & 0.5600 & 0.6073 & 0.6151 & 0.6521 \\
\hline 0.1938 & 0.5189 & -0.0162 & -0.0197 & -0.0406 & -0.0552 & -0.0837 & -0.0881 & -0.1092 \\
\hline 0.0619 & 0.6628 & 0.3587 & 0.3766 & 0.3919 & 0.3969 & 0.4341 & 0.4392 & 0.4652 \\
\hline 0.0447 & 0.3590 & -0.8071 & -0.8226 & -0.8578 & -0.8953 & -0.9363 & -0.9597 & -1.0126 \\
\hline 0.0350 & 0.1873 & 0.9791 & 1.0012 & 1.0285 & 1.0579 & 1.0985 & 1.1239 & 1.1614 \\
\hline 0.0316 & 0.1267 & -1.0845 & -1.0968 & -1.1254 & -1.2071 & -1.1829 & -1.1955 & -1.2174 \\
\hline \multirow[t]{3}{*}{0.0264} & 0.0353 & -1.0000 & -1.0014 & -1.0288 & -1.0331 & -1.0396 & -1.0480 & -1.0596 \\
\hline & & \multicolumn{7}{|c|}{ AAD (\%) } \\
\hline & & 0.4826 & 0.4946 & 0.5108 & 0.5227 & 0.5411 & 0.5508 & 0.5676 \\
\hline
\end{tabular}

presents somewhat higher errors, in this case the average relative deviation values fall between $1.18-1.3 \%$.

Table 7 shows the result of the temperature-density correlation with eq.(4) for biodiesel + diesel fuel + isopropanol ternary system. Eq.(4) shows $A A D$ errors between 0.1 and $1.5 \%$.

REV.CHIM. (Bucharest) $69 \diamond$ No. 12 \ 2018
Eqs.(1)-(4) can be practically used to calculate the density of the ternary studied fuels blends at different compositions and temperatures with average errors of $0.0021-1.7 \%$.

Figure 3 shows the density values calculated with the predictive eq.(1) and eq.(2) and the correlative equation, 
Table 6

PARAMETERS VALUES FROM EQ.(3) AND AVERAGE ABSOLUTE PERCENTAGE DEVIATION (AAD, \%) FOR DENSITY CORRELATION WITH COMPOSITION AT DIFFERENT TEMPERATURES

\begin{tabular}{|c|c|c|c|c|c|c|c|c|}
\hline & \multicolumn{7}{|c|}{ Temperature (K) } \\
\hline & & 293.15 & 298.15 & 303.15 & 308.15 & 313.15 & 318.15 & 323.15 \\
\hline \multirow{6}{*}{ Parameters } & $\mathrm{a}$ & 0.8664 & 0.8627 & 0.8590 & 0.8555 & 0.8517 & 0.8481 & 0.8445 \\
\hline & $\mathrm{b}$ & 0.8242 & 0.8204 & 0.8167 & 0.8129 & 0.8093 & 0.8054 & 0.8015 \\
\hline & $\mathrm{C}$ & 0.8204 & 0.8162 & 0.8120 & 0.8079 & 0.8037 & 0.7993 & 0.7948 \\
\hline & d & -0.2327 & -0.2349 & -0.2373 & -0.2410 & -0.2434 & -0.2467 & -0.2509 \\
\hline & $\mathrm{e}$ & 0.1049 & 0.1066 & 0.1087 & 0.1110 & 0.1132 & 0.1159 & 0.1176 \\
\hline & $\mathrm{f}$ & 0.0651 & 0.0644 & 0.0644 & 0.0630 & 0.0614 & 0.0611 & 0.0619 \\
\hline \multicolumn{2}{|l|}{$\mathrm{AAD}(\%)$} & 1.1877 & 1.2035 & 1.2205 & 1.2407 & 1.2593 & 1.2814 & 1.3001 \\
\hline
\end{tabular}

\begin{tabular}{|c|c|c|c|c|}
\hline \multirow{2}{*}{$\mathbf{w}_{1}$} & \multirow{2}{*}{$\mathbf{w}_{2}$} & \multicolumn{2}{|c|}{ Correlation parameters } & \multirow{2}{*}{ AAD (\%) } \\
\cline { 3 - 4 } & & $\mathbf{a}$ & $\mathbf{b}$ & \\
\hline 0.0966 & 0.0918 & -0.0007 & 1.0801 & 0.9915 \\
\hline 0.2082 & 0.0990 & -0.0008 & 1.0796 & 1.0104 \\
\hline 0.1960 & 0.1864 & -0.0008 & 1.0792 & 1.0312 \\
\hline 0.0985 & 0.2809 & -0.0008 & 1.0800 & 1.0574 \\
\hline 0.3921 & 0.0932 & -0.0008 & 1.0714 & 1.0770 \\
\hline 0.3959 & 0.1882 & -0.0008 & 1.0702 & 1.1036 \\
\hline 0.2984 & 0.2837 & -0.0008 & 1.0663 & 1.1221 \\
\hline 0.1999 & 0.3802 & -0.0008 & 1.0725 & 0.2107 \\
\hline 0.1005 & 0.4775 & -0.0008 & 1.0677 & 0.1024 \\
\hline 0.1025 & 0.6822 & -0.0009 & 1.0621 & 1.2525 \\
\hline 0.2040 & 0.5818 & -0.0008 & 1.0623 & 1.3710 \\
\hline 0.4039 & 0.3840 & -0.0008 & 1.0647 & 0.8847 \\
\hline 0.5999 & 0.1901 & -0.0008 & 1.0630 & 1.5324 \\
\hline 0.5940 & 0.0941 & -0.0008 & 1.0652 & 0.3580 \\
\hline 0.7999 & 0.0951 & -0.0008 & 1.0540 & 0.7962 \\
\hline 0.6059 & 0.2880 & -0.0008 & 1.0608 & 1.2320 \\
\hline 0.4080 & 0.4849 & -0.0008 & 1.0607 & 0.3580 \\
\hline 0.3075 & 0.5848 & -0.0008 & 1.0579 & 1.4716 \\
\hline 0.1036 & 0.7877 & -0.0009 & 1.0567 & 1.4873 \\
\hline & & & & \\
\hline
\end{tabular}

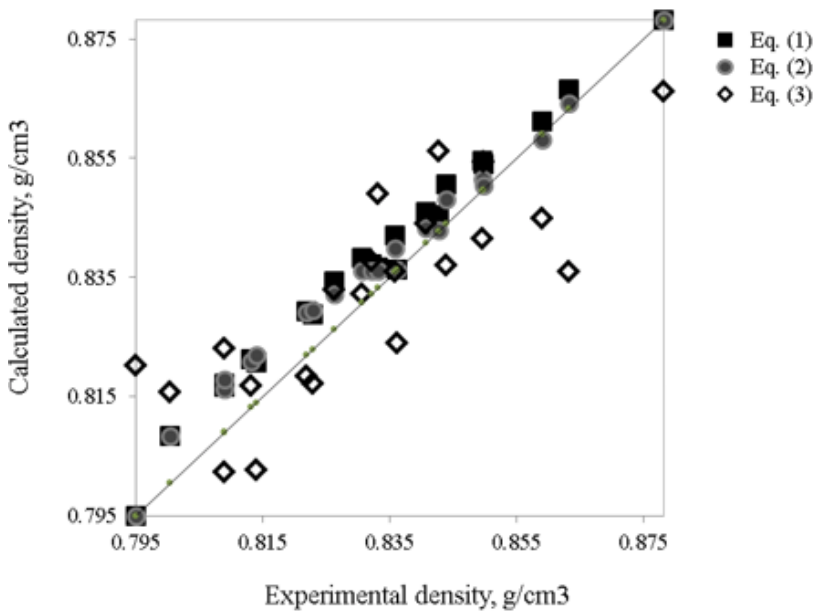

Fig.3. Calculated density with different equations versus experimental density at $293.15 \mathrm{~K}$ for biodiesel(1) + diesel fuel(2) + isopropanol(3) ternary system

eq.(3) as compared to the experimental values. It can be seen that the predictive equations present the best results, the dependency points are arranged near the bisector. These equations are accurate and give errors between 0.6 - $0.7 \%$ (eq.(1)), and $0.48-0.56 \%$ (eq.(2)). The low error values recommend them to be used for predictive computation. Correlative Eq.3 also shows small error values, which recommends itfor estimating the density of the studied ternary system.

The accurate results obtained with predictive equations (eqs.(1)and (2)) indicate an almost ideal behavior of the studied system. The pseudo-ternary system is probably a mixture of components molecules without or with very weak interactions between them.

\section{Table 7}

PARAMETERS VALUES FROM EQ.(4) AND AVERAGE ABSOLUTE PERCENTAGE DEVIATION (AAD, \%) FOR DENSITY CORRELATION WITH TEMPERATURE AT DIFFERENT COMPOSITIONS

\section{Conclusions}

Experimental densities of biodiesel+diesel fuel+ isopropanol system for temperature ranging from 293.15 to $323.15 \mathrm{~K}$ have been reported.

The density of the biodiesel + diesel fuel + isopropanol ternary system varies monotonously with mixture composition, without extreme points, with values within the range limited by the densities of the pure components. The predictive equations ((eq.(1) and (2)) which calculate the density of the mixtures from the density of the pure components, allow a good estimation, the errors being within $0.6-0.7$ and $0.48-0.56 \%$, respectively. The correlative equation with six parameters (eq.(3)) also represents well the experimental data, with errors between 1.18 and $1.3 \%$, being slightly higher than the errors corresponding to eq.(1) and eq.(2). The dependence of density on temperature is well represented by Eq.(4), the corresponding errors ranging from $0.10 \%$ to $1.53 \%$.

All equations used in this study to calculate the density of biodiesel + diesel fuel + isopropanol system can be utilized in practice to estimate the density of this ternary system at different compositions and temperatures. Biodiesel + diesel fuel + isopropanol ternary system is of practical interest because isopropanol addition decreases system density, making it more close to that of diesel fuel and thus permitting more biofuels to be added to fossil fuel. Isopropanol as a product of some more competitive biotechnologies that have been recently developed is a possible additive or substitute for fossil fuels.

\section{References}

1. ALPTEKIN, E., Fuel, 205, 2017, p.161.

2. SASTRY, G.R.K., MADHUJ IT, D.E.B., JIBITESH, K.P., Energy Procedia,

66, 2015, p. 81.

3. GULUM, M., BILGIN, A., Fuel, 199, 2017, p. 567.

4. SALEH, H.E., MOHAMED SELIM, Y.E., Fuel, 207, 2017, p. 690. 
5. SHAHIR, S.A., MASJUKI, H.H., KALAM, M.A., IMRAN, A., ASHRAFUL, A.M., Renew. Sust. Energ. Rev., 48, 2015, p. 62.

6. YILMAZ, N., ATMANLI, A., Fuel, 191, 2017, p. 190.

7. CAMPOS-FERNANDEZ, J., ARNAL, J.M., GÓMEZ, J., DORADO, M.P., Appl. Energ., 95, 2012, p. 267.

8. WEI, L., CHEUNG, C.S., HUANG, Z., Energy, 70, 2014, p. 172.

9. CAMPOS-FERNANDEZ, J., ARNAL, J.M., GOMEZ, J., LACALLE, N., DORADO, M.P., Fuel, 107, 2013, p.866.

10. ATMANLI, A., YUKSEL, B., ILERI, E., KARAOGLAN, A.D., Energ. Convers. Manage., 90, 2015, p.383.

11. BABU, D., ANAND, R., Energy, 133, 2017, p. 761.

12. HAO, L., SHUQIAN, X., HUIJUAN, L., PEISHENG, M., Fuel, 173, 2016, p. 52.

13. AVULAPATI, M.M., GANIPPA, L.C., JUN, X., MEGARITIS, A., Fuel, 166, 2016, p. 59.

14. COUGHLIN, B., HOXIE, A., Fuel, 196, 2017, p. 488.

15. IMDADUL, H.K., MASJUKI, H.H., KALAM, M.A., ZULKIFLI, N.W.M., ALABDULKAREM, A., RASHED, M.M., ASHRAFUL, A.M., Energ. Convers. Manage., 123, 2016, p. 252.

16. LIU, Y., XU, B., JIA, J., WU, J., SHANG, W., MA, Z., International Conference on Electrical, Electronics and Mechatronics, 2015, p.133. 17. HAZAR, H., UYAR, M., Int. J. Automotive Eng. Tech. (IJAET), 4, 2015, p.1.

18. GULUM, M., BILGIN, A., Int. J. of Smart Grid Clean Energ., 6, no. 3, 2017, p.177.
19. NITA, I., GEACAI, S., IULIAN, O., Renew. Energ., 63, no. 12, 2011, p.3417.

20. GEACAI, S., IULIAN, O., NITA, I., Fuel, 143, 2015, p.268.

21. NITA, I., GEACAI, E., OSMAN, S., IULIAN, O., Rev. Chim. (Bucharest), 67, no. 9, 2016, p.1763.

22. GEACAI, E., NITA, I., OSMAN, S., IULIAN, O., UPB Sci. Bull., Series B, 79, no. 1, 2017, p.11.

23. TRC Thermodynamic Tables, Thermodynamic Research Center, Texas A\&M University, College Station, TX, 1994.

24. KAO Y.C., CHEIN-HSIUN TU J., Chem. Thermodynamics, 43, 2011, p. 216.

25. RIDDICK J.A., BUNGER W.B., SAKANO T., Organic Solvents, 4th ed., J ohn Wiley, New York, 1986.

26. DUBEY G.P., SHARMA M., J. Chem. Therm., 41, 2009, p.115.

27. CLEMENTS D.L., Proceedings of the Third Liquid Fuels Conf. Am. Soc. Agric. Eng., 1996, p. 44.

28. PRATAS M.J, FREITAS S.V.D., OLIVEIRA M.B., MONTEIRO S.C., LIMA A.S., COUTINHO D. J.A.P, Energ. Fuel, 25, 2011, p. 2333. 29. TAT M.E., VAN GERPEN J.H., J. Am. Oil Chem. Soc, 77, no. 2, 2000, p. 115.

30. ALPTEKIN E., CANAKCI M., Renew. Energ., 33, no. 12, 2008, p. 2623.

31. YUAN W., HANSEN A.C, ZHANG Q., Fuel, vol. 88, 2009, p. 1120. 32. TESFA B., MISHRA R., GUA F., POWLES N., Renew. Energ., vol. 35, no.12, 2010, p. 2752.

Manuscript received: 8.01 .2018 